ACTA UNIVERSITATIS WRATISLAVIENSIS

PRZEGLĄD PRAWA I ADMINISTRACJI CXX/2

WROCŁAW 2020

https://doi.org/10.19195/0137-1134.120.56

\author{
RAJNHARDT KOKOT \\ ORCID: 0000-0002-6240-7282 \\ Uniwersytet Wrocławski \\ Katedra Prawa Karnego Materialnego
}

\title{
PENALIZACJA PRZYGOTOWANIA ZABÓJSTWA W NOWELIZACJI KODEKSU KARNEGO Z 13 CZERWCA 2019 ROKU
}

\begin{abstract}
Abstrakt: Artykuł podejmuje problematykę przygotowania zabójstwa, jego istoty i zasadności penalizacji. Takie zachowania w systemie prawa karnego pod rządami kolejnych jego kodyfikacji pozostawały bezkarne. Zmiana w tym zakresie nastąpiła wraz z nowelizacją kodeksu karnego z 13 czerwca 2019 roku. Przyjęta modyfikacja zasad odpowiedzialności karnej na ,przedpolu przedpola" dokonania zabójstwa rodzi liczne wątpliwości i kontrowersje. Przedmiotem opracowania jest więc próba uzasadnienia wprowadzonej zmiany oraz odpowiedzi na pytanie, w jaki sposób w ciągu bez mała wieku motywowano obowiązujący stan prawny w tym zakresie i czy zasadnie ustawodawca odszedł od tradycyjnego modelu bezkarności przygotowania zabójstwa.
\end{abstract}

Słowa kluczowe: przygotowanie, zabójstwo, karalność, penalizacja, formy stadialne, klauzula karalności, klauzula niepodlegania karze

\section{UWAGI WPROWADZAJĄCE}

Wiodącym założeniem zmian przyjętych w nowelizacji kodeksu karnego z 13 czerwca 2019 roku — co wyraźnie podkreślali jej autorzy — było obostrzenie odpowiedzialności karnej. Jak wynika z uzasadnienia projektuํㅜ, przyjęty kierunek zwiększenia punitywności rozwiązań prawnych miał być realizowany zarówno na płaszczyźnie części ogólnej, jak i szczególnej. Zaostrzenie odpowiedzialności w części szczególnej kodeksu karnego nastąpiło

${ }^{1}$ Projekt ustawy o zmianie ustawy — Kodeks karny oraz niektórych innych ustaw z dnia 25 stycznia 2019 roku, https://legislacja.rcl.gov.pl/docs//2/12320403/12565615/12565616/dokument378690. pdf (dostęp: 15.03.2019). 
w sposób selektywny i racjonalny, oparty na wnikliwej ocenie zasadności wzmocnienia prawnokarnej ochrony w określonych dziedzinach życia społecznego, w które prawo karne wkracza, stawiając tam ludzkim zachowaniom nieprzekraczalne granice ${ }^{2}$.

Wśród „dziedzin życia społecznego” wymagających bardziej stanowczej ingerencji prawa karnego i wzmożonej jego reakcji znalazła się sfera ochrony życia i zdrowia. Zmiany odnoszące się do tej grupy przestępstw idą w dwóch kierunkach. Pierwszy z nich wyraża się w obostrzeniu granic zagrożenia karą przewidzianych za niektóre przestępstwa stypizowane w tym rozdziale, między innymi zabójstwo w typie podstawowym oraz kwalifikowanym, nieumyślne spowodowanie śmierci, ciężki uszczerbek na zdrowiu czy udział w bójce lub pobiciu. Drugi kierunek zmian łączy się z wprowadzeniem nowych rozwiązań prawnych, dotąd niewystępujących w rozdziale przestępstw chroniących życie i zdrowie, w tym między innymi nowych typów przestępstw przeciwko życiu — przyjęcia zlecenia zabójstwa (art. 148a $\S 1$ k.k.) oraz kwalifikowanego typu nieumyślnego spowodowania śmierci więcej niż jednej osoby (art. 155 § 2 k.k.), a także karalności przygotowania zabójstwa (art. $148 \S 5$ k.k.). W znowelizowanym stanie prawnym czynności przygotowawcze mające na celu zabójstwo zagrożone zostały karą pozbawienia wolności od 2 do 15 lat.

$\mathrm{Na}$ tradycję unormowań polskiego prawa karnego składa się reguła niekaralności przygotowania przestępstwa. Bezkarność czynności przygotowawczych stanowi więc rodzaj „domyślnego” rozwiązania normatywnego. Karalność tej formy stadialnej ma charakter wyjątkowy i zachodzi tylko wówczas, gdy przepis części szczególnej kodeksu karnego lub ustawy pozakodeksowej — jednostkowo lub zbiorczo - wyraźnie ją wskazuje, operując tak zwaną klauzulą karalności przygotowania (art. 16 § 2 k.k.). Klauzula ta może się odnosić zarówno do pełnej formuły przygotowania określonego $\mathrm{w}$ art. $16 \S 1$ k.k., jak i jedynie do niektórych form realizacji tej postaci stadialnej. Penalizacja przygotowania, na co powszechnie zwraca się uwagę w piśmiennictwie, jest wyrazem subiektywizacji odpowiedzialności karnej - dotyczy bowiem zachowań, które jeszcze nie naruszają dobra prawnego, a jedynie uzewnętrzniają zamiar jego naruszenia, wprowadzając je w stan swoistego, potencjalnego narażenia. W obowiązującym kodeksie karnym można odnaleźć relatywnie niewiele przypadków karalności czynności przygotowawczych. W opracowaniach naukowych zwykle wymienia się ich kilkanaście. Różnice w przytaczanych w tym zakresie szczegółowych danych liczbowych wynikają ze sposobu prowadzonych obliczen — zwłaszcza zaś z interpretacji przepisów przewidujących zbiorowe klauzule karalności tej fazy stadialnej przestępstwa, a także liczby typów wyodrębnionych w poszczególnych przepisach określających zagrożone karą czynności przygotowawcze.

${ }^{2}$ Uzasadnienie projektu ustawy o zmianie ustawy - Kodeks karny oraz niektórych innych ustaw z dnia 25 stycznia 2019 roku, s. 27, https://egislacja.rcl.gov.pl/docs//2/12320403/12565615/ 12565616/dokument378691.pdf (dostęp: 15.03.2019). 
Penalizacja czynności przygotowawczych wyraża ustawowy kierunek intensyfikacji zwalczania zachowań szczególnie niebezpiecznych już na przedpolu karalność co do zasady usiłowania. Racjonalizacja przesunięcia ochrony prawa karnego na „przedpole przedpola” naruszenia dobra prawnego następuje na kilku płaszczyznach. Jak wskazuje się w doktrynie prawa karnego, karalność przygotowania uzasadniona jest zwłaszcza wysokim stopniem społecznej szkodliwości zamierzonych czynów, wynikającym ze szczególnej rangi chronionych dóbr. Ich społeczna wartość i znaczenie stanowią więc podstawowy czynnik legitymizujący karalność zachowań, które dobrom tym zagrażają jedynie pośrednio. W tym sensie penalizacja przygotowania jawi się jako działanie wtórne w stosunku do kryminalizacji zachowania głównego, pozostając w ścisłym związku z jego społecznym ciężarem i karygodnością. Zwiększoną społeczną szkodliwość przygotowania przestępstwa można wyprowadzać także $\mathrm{z}$ tego, iż istotnie rzutuje ono na ocenę strony podmiotowej zachowania sprawcy, zwiększając jednocześnie niebezpieczeństwo osiągnięcia zamierzonego przez niego celu. Podejmując „logistyczne" działania ukierunkowane na realizację objętego zamiarem, zaplanowanego skutku, sprawca z jednej strony wykazuje wpływający na ocenę jego zachowania rodzaj premedytacji, z drugiej natomiast istotnie zwiększa prawdopodobieństwo powodzenia podjętego w tych warunkach zamachu na dobro prawne. Penalizacja takich zachowań ma zatem niejako w zarodku zapobiegać jego naruszeniom ${ }^{3}$.

Za dopełniające kryterium karalności przygotowania uchodzić może kryterium braku możliwości - lub znacznego utrudnienia — dokonania określonego przestępstwa bez podjęcia wstępnych, dających się możliwie łatwo wyodrębnić na płaszczyźnie faktycznej, czynności przygotowawczych. Za karalnością przygotowania może więc przemawiać charakter określonego przestępstwa, którego realizacja z reguły nie może nastąpić bez określonych czynności aranżujących, bądź też same te czynności charakteryzują się już społeczną szkodliwością uzasadniającą reakcję prawa karnego. Na tej płaszczyźnie decydujące znaczenie dla decyzji ustawodawcy zdaje się mieć możliwość relatywnie łatwego uchwycenia i dowodowego wykazania realizacji znamion czynu zabronionego. Motywacja takiej decyzji legislacyjnej jest przy tym analogiczna jak w wypadku przestępstw abstrakcyjnego narażenia na niebezpieczeństwo, które nie wymagają sprowadzenia konkretnego zagrożenia dla dobra prawnego, a jedynie możliwości takiego zagrożenia ${ }^{4}$. Opiera się więc ona na swoistym „domniemaniu niebezpieczeństwa”, założeniu „generalnej niebezpieczności” pewnych czynności dla dobra prawnego,

${ }^{3}$ Por. E. Kunze, Przygotowanie przestępstwa w ujęciu polskiego prawa karnego, Poznań 1991, s. 7; A. Marek, Prawo karne, Warszawa 2011, s. 195.

${ }^{4}$ Por. K. Buchała, A. Zoll, Polskie prawo karne, Warszawa 1997, s. 290; W. Wróbel, A. Zoll, Polskie prawo karne. Część ogólna, Kraków 2010, s. 241. 
jeśli tylko są one przez sprawcę podejmowane w warunkach określonego w ustawie nastawienia wolicjonalnego ${ }^{5}$.

\section{DOTYCHCZASOWY STAN PRAWNY - UZASADNIENIE NIEKARALNOŚCI PRZYGOTOWANIA ZABÓJSTWA}

Obowiązujący kodeks karny przed nowelizacją z 13 czerwca 2019 roku nie przewidywał karalności przygotowania zabójstwa - niezależnie od jego typu. Bezkarne pozostawało więc zarówno przygotowanie zabójstwa w typie podstawowym, kwalifikowanym, jak i - co na tle poczynionych uwag jest najbardziej zrozumiałe - uprzywilejowanym. Karalności przygotowania zabójstwa nie znała też żadna wcześniejsza rodzima kodyfikacja karna ${ }^{6}$. $\mathrm{Z}$ tej perspektywy rozwiązanie przyjęte $\mathrm{w}$ art. $148 \S 5 \mathrm{k} . \mathrm{k}$. jest zatem niewątpliwie rozwiązaniem bezprecedensowym w historii polskiego prawa karnego. Zapewne także $\mathrm{z}$ tego powodu budzi ono liczne wątpliwości i kontrowersje. Już w toku prac nad projektem kodeksu karnego rozwiązanie to spotkało się z surową krytyką, zarówno środowiska nauki prawa karnego, jak i praktyki wymiaru sprawiedliwości, wyrażaną w wielu opiniach dotyczących projektowanych rozwiązań, odwołujących się do argumentacji uzasadniającej walory dotychczasowego status quo i wykazującej niecelowość i liczne ryzyka wynikające z przesunięcia ochrony życia w fazę działań sprawcy, mocno niepewną na płaszczyźnie procesowego dowodzenia realizacji znamion czynu zabronionego.

W piśmiennictwie wśród powodów braku penalizacji przygotowania zabójstwa zwraca się uwagę zwłaszcza na trudności natury dowodowej związane z bez-

${ }^{5}$ Niezależnie od ogólnej klauzuli karalności przygotowania jako najwcześniejszej fazy stadialnej określonego typu przestępstwa ustawa przewiduje także przypadki, w których wyizolowane z art. 16 § 1 k.k. „,zynności przygotowawcze” znajdują się w dyspozycji przepisu karnego określającego autonomiczny typ przestępstwa sui generis, którego ustawowe znamiona jedynie odpowiadają treścią czynnościom przygotowawczym. Ich kompleksowa realizacja stanowi więc dokonanie przestępstwa. Do zachowań tego rodzaju nie odnoszą się zatem przepisy szczególne dotyczące przygotowania, na przykład regulujące klauzule bezkarności tej fazy stadialnej. Nie można jednocześnie wykluczyć, choć w praktyce nie są to przypadki łatwe do wskazania, możliwości wyczerpania ich znamion $\mathrm{w}$ formach stadialnych na przedpolu dokonania, $\mathrm{w}$ tym $\mathrm{w}$ formie przygotowania $\mathrm{w}$ ujęciu art. $16 \S 1$ k.k. W tym zakresie sytuacja kształtuje się odmiennie w wypadku „klasycznych” klauzul karalności działań na przedpolu usiłowania.

${ }^{6}$ Przewidywały ją natomiast niektóre dawne ustawodawstwa obce, czasowo obowiązujące na ziemiach polskich do chwili wejścia w życie kodeksu karnego z 1932 roku. Karalność przygotowania zabójstwa regulował art. 457 rosyjskiego kodeksu karnego z 1903 roku. W austriackiej ustawie karnej z 1852 roku przygotowanie wszelkich zbrodni stanowiło okoliczność obciążającą, tym bardziej, im „rozmyślniejsze” było przygotowanie (§ 43). Analogicznie w akcie tym traktowano przygotowanie występków ( 263 lit. i). Karalności zabójstwa w formie przygotowania nie przewidywał za to kodeks niemiecki z 1871 roku. Karalne było jednak przygotowanie zdrady stanu mającej postać zabójstwa panującego (§§ 80-83).

Przegląd Prawa i Administracji CXX, 2020, cz. 1 i 2

(C) for this edition by CNS 
spornym wykazaniem realizacji strony podmiotowej takiego czynu. Czynności przygotowawcze do zamachu na życie z reguły nie pozwalają bowiem na jednoznaczne i niewątpliwe ustalenie, iż zostały one podjęte z zamiarem bezpośrednim zorientowanym na skutek śmiertelny. Jak w tym kontekście zauważa T. Bojarski, karalność przygotowania czynu zabronionego ustawa ogranicza do typów przestępstw, „przy których czynność przygotowawcza daje się łatwo rozpoznać jako właśnie czynność nastawiona na stworzenie warunków do dokonania przestępstwa w przyszłości”, w tych natomiast przypadkach — do których autor zalicza także przestępstwo zabójstwa — w których czynności przygotowawcze są , trudno rozpoznawalne jako przedsiębrane w tym właśnie celu" i które nie dają się łatwo odróżnić od „Zwykłych czynności dnia codziennego", zachowania takie pozostają bezkarne?

Polskie prawo karne nie przewidywało karalności przygotowania do zbrodni zabójstwa, albowiem zwykle realizacja jego znamion - jak argumentowano w piśmiennictwie - następuje przy pomocy przedmiotów powszechnie dostępnych, używanych przez sprawców jako narzędzia przestępstwa, gromadzenie zaś określonych informacji może służyć też innym celom ${ }^{8}$. Niepodobna w większości takich wypadków wykazać, że osoba podejmująca określone działania istotnie czyni przygotowanie do zbrodni zabójstwa. Jak dosadnie w odniesieniu do przygotowania zabójstwa trudność tę ilustruje M. Małecki, chodzi o to, iż z reguły trudno ustalić, czy sprawca „kupuje nóż po to, by pokroić chleb, czy po to, by pokroić sąsiada"9. Jak wynika z przywołanych argumentów, o dotychczasowym braku penalizacji przygotowania zabójstwa decydowały przede wszystkim względy „praktyczne”, wynikające z trudności procesowych w toku dowodzenia realizacji znamion przygotowania, zwłaszcza subiektywnych; doniosłość i wartość dobra, jakim jest życie człowieka, niewątpliwie bowiem predestynowały je do ochrony już na dalszym niż usiłowanie przedpolu jego naruszenia, a więc na etapie jego pośredniego narażenia wynikającego z przygotowania zamachu.

\section{UZASADNIENIE KLAUZULI KARALNOŚCI Z ART. 148 § K.K.}

W kontekście regulacji art. $148 \S 5$ k.k. pojawia się pytanie o ratio legis karalności przygotowania zabójstwa. Jak już wspomniano, karalność przygotowania z reguły pozostaje w związku z ciężarem danego typu przestępstwa. Kryterium to, jak można wyinterpretować $\mathrm{z}$ uzasadnienia projektu nowelizacji kodeksu

7 T. Bojarski, Polskie prawo karne. Zarys części ogólnej, Warszawa 2006, s. 191.

${ }^{8}$ Por. A. Marek, Kodeks karny. Komentarz, Warszawa 2004, s. 152-153; W. Świda, Prawo karne, Warszawa 1989, s. 189; por. także K. Mioduski, [w:] J. Bafia, K. Mioduski, M. Siewierski, Kodeks karny. Komentarz, Warszawa 1987, s. 72.

9 M. Małecki, Przygotowanie do przestępstwa. Analiza dogmatycznoprawna, Warszawa 2016, s. 21-22. 
karnego, zadecydowało też o karalności przygotowania zabójstwa. Jak wynika z argumentacji, czy raczej ogólniejszych tez mających racjonalizować tę zmianę, sformułowanych przez autorów nowego rozwiązania normatywnego, „są to zachowania wysoce społecznie szkodliwe i z punktu widzenia aksjologii systemu prawa karnego materialnego wymagają penalizacji" 10 . W obliczu takiej oceny nie można wszakże nie zauważyć, że w obowiązującym stanie prawnym waga czynu zabronionego, jako kryterium penalizacji przygotowania, nie jest ani kryterium niezawodnym, ani kategorycznym, a raczej orientacyjnym. Wyprowadzona na podstawie tej prawidłowości reguła zna bowiem liczne wyjątki o przeciwnych biegunach ${ }^{11}$. Nie można także tracić z pola widzenia tego — na co zwraca uwagę M. Małecki - iż w wypadku czynności przygotowawczych uzasadnienie karalności odwołujące się do poważnego zagrożenia dla dobra prawnego może mieć jedynie ograniczone zastosowanie, ponieważ przygotowanie przestępstwa jest formą abstrakcyjnego narażenia dobra prawnego na niebezpieczeństwo, którego eskalacja jest uzależniona od dalszego postępowania konkretnego sprawcy ${ }^{12}$.

W doktrynie prawa karnego postulat karalności przygotowania zabójstwa formułowany był od dawna. Trzeba wszakże przyznać, iż nie należał on ani do głównego, ani licznie reprezentowanego w nauce nurtu propozycji usprawnienia normatywnych mechanizmów ochrony życia. Zwolennicy zmian w zakresie prawnokarnej oceny przygotowania zabójstwa podnosili, iż trudno zracjonalizować stanowisko ustawodawcy, który penalizuje przygotowania znacznie łagodniejszych przestępstw niż zamachy na życie, natomiast jedna z najpoważniejszych zbrodni, jaką jest zabójstwo, na tym etapie pozostaje bezkarna ${ }^{13}$.

10 Uzasadnienie projektu ustawy o zmianie ustawy - Kodeks karny oraz niektórych innych ustaw z dnia 25 stycznia 2019 roku, s. 30, https:/legislacja.rcl.gov.pl/docs//2/12320403/12565615/ 12565616/dokument378691.pdf (dostęp: 15.03.2019).

$11 \mathrm{Z}$ jednej strony ustawa kryminalizuje przygotowanie fałszowania dokumentów zagrożone karą od 3 miesięcy do 5 lat pozbawienia wolności, a więc karą relatywnie łagodną (art. 270 § 3 k.k.), czy też przygotowanie przestępstwa dezercji zagrożonej w typie podstawowym analogiczną karą (art. 339 § 4 k.k.), z drugiej natomiast pozostawia bezkarne przygotowanie wielu ciężkich zbrodni skierowanych przeciwko dobrom o podstawowym znaczeniu zarówno dla jednostki, jak i całego społeczeństwa.

12 M. Małecki, op. cit., s. 19.

$13 \mathrm{Na}$ kwestię potrzeby karalności przygotowania zabójstwa wielokrotnie — pod rządami kolejnych kodyfikacji karnych — zwracała uwagę K. Daszkiewicz, podkreślając, iż zakres karalności przestępstw popełnionych $\mathrm{w}$ formie przygotowania, $\mathrm{w}$ tym najcięższych zbrodni, ulega postępującemu zawężeniu, co istotnie ogranicza możliwość skutecznej ochrony najważniejszych dóbr prawnych przed przygotowanymi na te dobra zamachami. Bezkarność przygotowania zabójstwa budziła wątpliwości zwłaszcza w tych sprawach, jak argumentowała badaczka, „które ujawniają szeroki zakres i intensywność czynności przygotowawczych". Autorka zwracała uwagę na rzucające się w oczy przykłady niekonsekwencji ustawodawcy w typizowaniu przestępstw karalnych już w fazie przygotowania. W kontekście jednej z cięższych odmian zabójstwa zdumienie może wywoływać fakt, iż przestępstwo wzięcia zakładnika jest karalne w fazie przygotowania (art. $252 \S 3$ k.k.) — co uznawała za rozwiązanie ze wszech miar właściwe - natomiast zabójstwo popełnione w związku z tym przestępstwem pozostaje bezkarne, z czym już niepodobna się zgodzić. Zob. eadem, Glosa 
Jak wcześniej wspomniano, podstawowym powodem i uzasadnieniem odstąpienia od penalizacji przygotowania zabójstwa podnoszonym przez zwolenników dotychczasowego stanu prawnego była obawa przed możliwymi w praktyce trudnościami dowodowymi, które są tak duże, iż przyjęcie karalności tej postaci przestępstwa wiązałoby się ze zbyt dużym ryzykiem pociągania do odpowiedzialności za zachowania, które przedmiotowo odpowiadając czynnościom przygotowawczym zabójstwa, nie realizują jednak jego warstwy subiektywnej.

W kontekście tego argumentu należy zwrócić uwagę na dwie okoliczności. Po pierwsze, wspomniane trudności z dowodzeniem treści intencjonalnych mają zakres znacznie wybiegający poza ramy realizacji znamion przygotowania zabójstwa, ich charakter jest bowiem, co do zasady, uniwersalny. Takie wątpliwości mogą wszakże towarzyszyć nie tylko przygotowaniu zabójstwa, lecz przygotowaniu każdego innego typu przestępstwa. „Niedostatki manifestacyjne” przygotowania, jak ujmuje to M. Małecki, są bowiem genetycznie wpisane w ten etap pochodu przestępstwa ${ }^{14}$. Po drugie, nie bierze on pod uwagę takich przypadków działań podejmowanych na przedpolu usiłowania, co do których na płaszczyźnie faktycznej nie ma jakichkolwiek wątpliwości, iż realizują zarówno treści przedmiotowe, jak i podmiotowe przygotowania zabójstwa.

$\mathrm{W}$ takim dowodowo niewątpliwym przypadku $\mathrm{w}$ dotychczasowym stanie prawnym organy ścigania pozostawały bezradne. Zmuszone były do oczekiwania, aż sprawca wejdzie w karalną — co do zasady — fazę usiłowania zabójstwa, mogąc tym samym narażać życie człowieka na dodatkowe, zwiększone ryzyko jego naruszenia, w tym większą skalę tego naruszenia. Skutki takiego „przeczekanego” podjęcia działań przez organy ścigania mogły być w takich wypadkach bardzo poważne, zarówno na płaszczyźnie materialnoprawnej, jak i procesowej. Wymuszone w takich warunkach zaniechanie działań organów ścigania z tej perspektywy trudno byłoby uznać za racjonalne. Taki stan mógł być postrzegany przez pryzmat naruszenia powinności zapewnienia należytej czy choćby dostatecznej ochrony dóbr prawnych, zarówno o charakterze indywidualnym, jak i kolektywnym. Na etapie przed usiłowaniem zabójstwa karalne mogły być zatem jedynie te przygotowania, które jednocześnie realizowały znamiona innego typu czynu zabronionego (na przykład nielegalne posiadanie broni palnej lub materiałów wybuchowych,

do wyroku SN z 23 października 1967 r., III KR 113/67, „Orzecznictwo Sądów Polskich i Komisji Arbitrażowych” 1968, nr 7-8, s. 375; eadem, Zbyt wiele niekonsekwencji i chaosu, „Rzeczpospolita” 1998, nr 76, s. 15; eadem, Przestęstwa przeciwko życiu i zdrowiu. Rozdziat XIX Kodeksu karnego. Komentarz, Warszawa 2000, s. 48-49, 54, 124, 127; tak też: E. Kunze, op. cit., Poznań 1991, s. 101. Także zdaniem R. Zawłockiego, wykazującego znacznie większą powściągliwość w ocenie potrzeby zmian status quo w zakresie unormowań przepisów chroniących życie, niekaralność zabójstwa w fazie przygotowania, zważywszy, iż jest to niewątpliwie zamach na dobro społeczne szczególnie wysokiej wartości, jawi się jako „swoista niekonsekwencja ustawodawcy” wynikająca wyłącznie z powodów „,praktycznych” — idem, [w:] Kodeks karny. Część ogólna, t. 1, red. M. Królikowski, R. Zawłocki, Warszawa 2011, s. 663-664.

14 M. Małecki, op. cit., s. 22. 
które miały być wykorzystane do zamachu na życie). W tych, nielicznych zresztą przypadkach, sprawca mógł być ścigany za realizację znamion czynu zabronionego, który miał być jedynie narzędziem czy środkiem na drodze do popełnienia zbrodni zabójstwa, a więc - w rzeczy samej — nie za to, co przygotowywał, obejmując swoim zamiarem ,strategicznym”, ale za to, jak się do tego przygotowywał, a więc jedynie w granicach realizacji zamiaru ,taktycznego”. Sprawca nie ponosił zatem odpowiedzialności karnej, mimo że jego niewątpliwy in concreto zamiar zabójstwa znalazł uzewnętrznienie w podejmowanych działaniach przygotowawczych. Odpowiadał więc w sposób ograniczony w stosunku do działań, które mogły być mu przypisane, zarówno od strony przedmiotowej, jak i podmiotowej.

Niekaralność przygotowania zabójstwa stanowiła jednocześnie wyraz swoistej niespójności rozwiązań prawnych chroniących życie człowieka na etapie przed wejściem sprawcy w fazę usiłowania jego naruszenia. Takie zachowania zostały w ustawie karnej w wielu wypadkach stypizowane i zagrożone karą. Przyjęta zmiana wpisuje się tym samym w szerszą perspektywę karalności zamachów na życie określoną w innych rozdziałach kodeksu karnego z 1997 roku. Mimo bowiem że zabójstwo jako typ przestępstwa stypizowanego w rozdziale XIX kodeksu karnego w fazie przygotowania „tradycyjnie” było bezkarne, przepisy regulujące, co do zasady, ochronę innych dóbr, a chroniące obocznie także życie człowieka, w wielu przypadkach przygotowanie do takich zamachów penalizowały ${ }^{15}$.

Niekaralność przygotowania zabójstwa, jako przestępstwa polegającego na potencjalnym narażeniu życia człowieka, stanowiła jednocześnie przejaw niekonsekwencji ustawodawcy, skoro narażenie życia — zarówno na niebezpieczeństwo konkretne, jak i abstrakcyjne - w innych okolicznościach niż związane z przy-

15 Jak wynika z art. 126c $\S 1$ k.k., w fazie przygotowania karane jest między innymi przestępstwo eksterminacji, którego realizacja może polegać na dopuszczeniu się zabójstwa „w celu wyniszczenia w całości albo w części grupy narodowej, etnicznej, rasowej, politycznej, wyznaniowej lub grupy o określonym światopoglądzie" (art. $118 \S 1$ k.k.), a także zbrodnia stosowania środka masowej zagłady (art. 120 k.k.). Jak z kolei stanowi art. 126c § 2 k.k., karalne jest też między innymi przygotowanie do stypizowanego w art. 118a § 1 k.k. „dopuszczenia się zabójstwa” w warunkach „masowego zamachu” określonego w tym przepisie, a także przygotowanie do „dopuszczenia się zabójstwa" jednej z kategorii osób w sposób szczególny chronionych prawem międzynarodowym (art $123 \S 1$ k.k.). Na marginesie należy zwrócić uwagę, że przewidziane w art. 126c granice karalności za przygotowanie do przestępstw przeciwko życiu z art. 118, art. 118a § 1 lub $\S 2$ oraz art. 123 k.k. nie korespondują — są bowiem albo wyższe: od 3 do 20 lat pozbawienia wolności, albo niższe: od roku do lat 10 — z granicami odpowiedzialności za wprowadzone mocą nowelizacji karalne przygotowanie do zabójstwa w rozumieniu przepisu art. $148 \S 5$, który granice te sytuuje w przedziale od 2 do 15 lat pozbawienia wolności, co rzecz jasna pozostaje w związku z „kontekstem faktycznym” przygotowanych zamachów na życie. Wydaje się jednak, iż tak znaczne rozbieżności w ocenie zachowań pośrednio zmierzających przecież do naruszenia tego samego dobra prawnego, przy możliwej analogicznej skali przygotowanego naruszenia, wymagałyby korekty w kierunku zwiększenia symetrii punitywności takich działań. 
gotowaniem zabójstwa zostało w ustawie karnej w wielu wypadkach stypizowane i zagrożone karąi ${ }^{16}$.

\section{PODMIOT I STRONA PODMIOTOWA PRZYGOTOWANIA ZABÓJSTWA W UJĘCIU ART. 148 § 5 K.K.}

Przygotowanie zabójstwa w znowelizowanym ujęciu art. 148 k.k. jest przestępstwem powszechnym. Jego sprawcą może być każdy, kto spełnia ogólne wymogi odpowiedzialności karnej. Odpowiedzialności na podstawie art. $148 \S 5$ k.k. nie poniesie sprawca nieletni, który dopuszcza się zamachu przeciwko życiu w warunkach art. $10 \S 2$ k.k. Wprawdzie przepis ten przewiduje możliwość pociągnięcia do odpowiedzialności za zabójstwo określone w art. 148 §§ 1-3 k.k., jednak regulacja ta odnosi się jedynie do postaci dokonanej oraz usiłowanej ${ }^{17}$. Przygotowanie zabójstwa w jednym z typów wskazanych w art. $148 \S 5$ k.k. jest przestępstwem o innej kwalifikacji prawnej, innym zespole znamion wynikającym z art. $16 \S 1$ k.k. w związku z przepisem typizującym przygotowaną postać zabójstwa oraz o innej sankcji niż typy zabójstwa wskazane w art. $10 \S 2$ k.k., wynikającej z art. $148 \S 5$ k.k.

Przygotowanie zabójstwa ma charakter przestępstwa kierunkowego. Jego znamiona mogą być zrealizowane tylko w zamiarze bezpośrednim o szczególnym zabarwieniu (dolus coloratus). Sprawca — zgodnie z ogólną formułą art. 16 $\S 1$ k.k. — „W celu popełnienia czynu zabronionego”, w tym wypadku zabójstwa $\mathrm{w}$ jednej ze wskazanych $\mathrm{w}$ przepisie postaci, podejmuje czynności mające stworzyć warunki do przedsięwzięcia czynu zmierzającego bezpośrednio do jego dokonania. Realizacja przedmiotowej warstwy przygotowania zabójstwa w warunkach godzenia się na jego popełnienie (dolus eventualis) nie spełnia wymogu strony podmiotowej wynikającej z art. $16 \S 1$ k.k. (na przykład sprawca nabył broń palną w celu sportowym, dopuszczając możliwość popełnienia przy jej użyciu zabójstwa). W tym kontekście podkreślenia wymaga znaczenie strony podmio-

16 Karalność zachowań wiążących się z „zagrożeniem” życia — poza art. 160 §§ 1-2 k.k. — wynika także z art. 168 k.k. Za przygotowanie między innymi do „sprowadzenia zdarzenia, które zagraża życiu lub zdrowiu wielu osób" (art. 163 § 1 k.k.) grozi kara 3 lat pozbawienia wolności. Na podstawie tego samego przepisu, w analogiczny sposób, zagrożone karą jest również przygotowanie przestępstwa sprowadzenia takiego samego niebezpieczeństwa $\mathrm{w}$ warunkach określonych $\mathrm{w}$ art. $165 \S 1$ k.k. W tę kategorię zamachów karalnych już w fazie przygotowania wpisuje się także przestępstwo stypizowane w art. 167 § 1 k.k., z którego wynika „zagrożenie bezpieczeństwa osób”. Wreszcie wskazać można art. 175 k.k., który przewiduje karalność przygotowania przestępstwa sprowadzenia katastrofy w komunikacji zagrażającej między innymi „życiu lub zdrowiu wielu osób” (art. $173 \S 1$ k.k.).

17 Por. A. Zoll, [w:] Kodeks karny. Część ogólna. Komentarz, t. 1, red. A. Zoll, Warszawa 2007, s. 136; odmiennie: A. Grześkowiak, [w:] Kodeks karny. Komentarz, red. A. Grześkowiak, K. Wiak, Warszawa 2018, s. 133. 
towej w konstrukcji tej formy przestępstwa. Jest ona bowiem czynnikiem, który decyduje o ujemnej zawartości czynności przygotowawczych ${ }^{18}$. W aspekcie jedynie przedmiotowym czynności podejmowane przez sprawcę $\mathrm{w}$ celu popełnienia zabójstwa z reguły nie wykazują, jak już wspomniano, żadnego stopnia naganności, a jeśli nawet, to wiąże się to $\mathrm{z}$ naruszeniem lub narażeniem innych dóbr niż życie człowieka. Dopiero więc ustalenie nagannego „celu” przyświecającego sprawcy podejmującemu określone działania uzasadnia karalność takich czynności. Zarówno uzyskiwanie lub przysposabianie określonych środków, zbieranie informacji, sporządzanie planu określonego działania, jak i wejście z inną osobą w porozumienie, obiektywnie rzecz biorąc, nie ma jeszcze żadnego ładunku ujemnego. Taki uzyskują dopiero wraz z ustaleniem celu, w jakim działania te zostały podjęte. To, rzecz jasna, aktualizuje powszechnie znane i podnoszone w nauce prawa karnego trudności z dowodzeniem określonych treści intencjonalnych po stronie sprawcy. Jest to już jednak kwestia o procesowoprawnym charakterze.

\section{ZAKRES PENALIZACJI PRZYGOTOWANIA ZABÓJSTWA I PRZEDMIOTOWE ASPEKTY REALIZACJI JEGO ZNAMION}

Jak wynika wprost $\mathrm{z}$ art. $148 \S 5$ k.k., karalne jest jedynie przygotowanie zbrodni zabójstwa określonych w art. $148 \S \S 1-3$ k.k. Przepis art. $148 \S 5$ k.k. nie obejmuje natomiast klauzulą karalności przygotowania występków przeciwko ży$\mathrm{ciu}^{19}$. Przyjęte rozwiązanie pozostaje więc w związku z ciężarem przygotowanego zabójstwa, obejmując tylko przypadki najcięższych zamachów na życie. Pomimo więc iż nie tylko teoretycznie wyobrazić można sobie także przygotowanie zabójstwa typu uprzywilejowanego, zwłaszcza zabójstwa eutanatycznego, takie zachowania niezmiennie pozostają na gruncie polskiego prawa bezkarne. Decyzja ustawodawcy w tym zakresie wpisuje się w ogólniejszą, wspomnianą wcześniej prawidłowość, że o karalności przygotowania określonego przestępstwa w większości wypadków decyduje ciężar przestępstwa, do którego sprawca podejmuje przygotowanie. $\mathrm{W}$ tym przypadku o zaniechaniu tej karalności przesądza istotnie rzutująca na ocenę stopnia społecznej szkodliwości wymienionych zamachów na życie ich szczególna strona podmiotowa.

Od strony przedmiotowej pośrednie zmierzanie do dokonania zabójstwa może wyrażać się każdym zachowaniem stwarzającym warunki do usiłowania

18 Por. J. Giezek, [w:] Prawo karne materialne, red. M. Bojarski, J. Giezek, Z. Sienkiewicz, Warszawa 2017, s. 261.

19 Bezkarne pozostaje więc zarówno przygotowanie zabójstwa eutanatycznego z art. $150 \S 1$ k.k. oraz dzieciobójstwa (art. 149 k.k.), jak i — znacznie trudniejsze do wyobrażenia w praktyce, ze względu na charakteryzujący te zamachy zamiar nagły, impulsywny, „,okolicznościowy”, „,sytuacyjny”, o cechach afektu, choć przecież teoretycznie możliwe - przygotowanie występku zabójstwa pod wpływem silnego wzburzenia usprawiedliwionego okolicznościami (art. 148 § 4 k.k.). 
jego popełnienia, w tym, jak wprost wskazuje art. $16 \S 1$ k.k., w szczególności: wejściem w porozumienie $\mathrm{z}$ inną osobą - a także na zasadzie wnioskowania a minori ad maius $\mathrm{z}$ większą ich liczbą — mającym na celu popełnienie zabójstwa; uzyskiwaniem lub przysposabianiem — determinowanym takim samym celem środków mających służyć popełnieniu zbrodni zabójstwa; wreszcie zbieraniem informacji lub sporządzaniem planu działania mających stworzyć warunki do wejścia w fazę jej usiłowania. Chodzi zatem o wszelkie zachowania pośrednio służące popełnieniu zabójstwa, które wypełniają przestrzeń między powzięciem zamiaru zabicia człowieka a wejściem w fazę jego usiłowania. Stopień zaangażowania sprawcy w czynności przygotowawcze oraz ich zakres rzeczowy i czasowy może wpływać na sądowy wymiar kary za tę postać stadialną. Znamiona przygotowania zabójstwa mogą być wyczerpane w warunkach sprawstwa pojedynczego lub w konfiguracji wieloosobowej. Wyłącznie w warunkach współsprawstwa mogą być natomiast wyczerpane znamiona przygotowania zabójstwa w formie „wejścia w porozumienie z inną osobą" w celu popełnienia zabójstwa.

Przygotowanie zbrodni zabójstwa - co wynika z ogólnej ustawowej formuły zawartej w art. $16 \S 1$ k.k. - musi mieć postać działania ${ }^{20}$. Ex definitione, ,podejmowanie czynności" mających stworzyć warunki do usiłowania zabójstwa — zwłaszcza tych, które expressis verbis, jako przykładowe, zostały wymienione w tym przepisie — nie może nastąpić $\mathrm{w}$ formie zaniechania. Zgodnie z treścią art. $18 \S 3$ zd. 2 k.k. w ten sposób, teoretycznie, można by zrealizować znamiona pomocnictwa do przygotowania. Sama możliwość przyjęcia karalności niesprawczych form przygotowania w piśmiennictwie karnistycznym jest jednak źródłem licznych kontrowersji.

Przygotowanie zabójstwa, jako autonomiczną formę stadialną tego typu przestępstwa, należy interpretować przez pryzmat ogólnych unormowań realizacji tej fazy przestępstwa. Regulacji art. 148 § 5 k.k., przewidującego karalność przygotowania określonych w tym przepisie odmian zabójstw, nie można więc traktować jako przepisu statuującego odrębny typ przestępstwa (sui generis), a wyłącznie jako przepis penalizujący tę formę stadialną. Przepis ten, jak wcześniej podkreślono, nie kreuje bowiem autonomicznego przestępstwa, a jedynie rozciąga odpowiedzialność karną na zachowania pośrednio zmierzające do dokonania jednej ze zbrodni w nim wymienionych. Artykuł $148 \S 5 \mathrm{k} . \mathrm{k}$. nie określa więc typu „zabójstwa przygotowanego”, a jedynie przewiduje karalność „przygotowania zabójstwa" jako formy stadialnej na drodze do dokonania tego przestępstwa. Należy tym samym wykluczyć możliwość przygotowania do przygotowania, a także usiłowania przygotowania zabójstwa. Przyjęcie przeciwnego stanowiska prowadziłoby do penalizacji zachowań na przedpolu przedpola usiłowania zabójstwa. Choć pojęciowo takich przypadków nie można wykluczyć, karalne może być tylko „dokonane” przygotowanie zabójstwa ${ }^{21}$.

20 Por. A. Liszewska, [w:] System Prawa Karnego, t. 3, red. R. Dębski, Warszawa 2017, s. 855.

21 Por. R. Zawłocki, op. cit., s. 650; J. Giezek, op. cit., s. 265. 
Sporna na gruncie nauki prawa karnego jest kwestia przygotowania zjawiskowych form współdziałania przestępnego. W praktyce przygotowanie odnosi się najczęściej do wykonawczych form realizacji znamion przestępstwa, a więc do sprawstwa bądź współsprawstwa. Możliwe jest jednak także zarówno przygotowanie do niewykonawczych form sprawstwa, jak i form niesprawczych ${ }^{22}$. Odrębnym źródłem sporu na gruncie doktryny jest stopień karygodności tych form przygotowania, uzasadniający potrzebę odpowiedzialności karnej w takim wypadku ${ }^{23}$. Na tym tle jeszcze większe wątpliwości i kontrowersje może wzbudzać kwestia niesprawczych form przygotowania zabójstwa, a więc przypadek swoistego odwrócenia wcześniej wspomnianej relacji. Innymi słowy, czy można nakłaniać, względnie ułatwiać — w rozumieniu art. 18 § 2-3 k.k. — popełnienie przestępstwa przygotowania zabójstwa. Problem ten, nieco upraszczając sprawę, sprowadza się do pytania, czy możliwe jest pojęciowe wyizolowanie podżegania czy pomocnictwa do przygotowania zabójstwa, które nie stanowiłoby jednocześnie podżegania czy pomocnictwa do popełnienia tego przestępstwa w formie dokonania. Punktem wyjścia do interpretacji takiego przypadku musi być teza, że pojęciowo nie jest możliwe podżeganie do jakiegokolwiek czynu zabronionego (podżeganie do przestępstwa w ogóle), lecz jedynie podżeganie do określonego typu czynu zabronionego. Teoretycznie przypadek taki można sobie wyobrazić2 ${ }^{24}$. Jednak w praktyce oddzielenie nakłaniania czy pomocnictwa do przygotowania zabójstwa od nakłaniania czy pomocnictwa do dokonania zabójstwa będzie bardzo utrudnione, a $\mathrm{z}$ reguły wręcz niemożliwe. Wszakże podżegacz, względnie pomocnik, odpowiednio nakłaniają do bądź pomagają w popełnieniu określonego typu przestępstwa, nie zaś w jego określonej postaci stadialnej, to natomiast, za jaką fazę stadialną poniesie odpowiedzialność sprawca wykonawczy, zależy od zaawansowania realizacji przez niego znamion danego czynu zabronionego, do którego był nakłaniany lub przy wykonaniu którego mu pomagano.

${ }^{22}$ Można zilustrować to przykładami zawarcia porozumienia co do kierowania zabójstwem, polecenia zabójstwa czy udzielenia pomocy do popełnienia zabójstwa. Przygotowaniem do zabójstwa może być między innymi gromadzenie środków finansowych mających służyć opłaceniu zabójcy na zlecenie. W kontekście typizacji przestępstwa przyjęcia zlecenia zabójstwa z art. 148a § 1 k.k. ten, kto zleca takie zabójstwo, odpowiada za podżeganie do zabójstwa. Byłby więc to przykład przygotowania do podżegania do zabójstwa.

23 Por. P. Kardas, [w:] Kodeks karny. Część ogólna. Komentarz, t. 1, s. 318; R. Zawłocki, op. cit., s. 644-645, 652, 654; A. Liszewska, op. cit., s. 861; odmiennie: E. Kunze, op. cit., s. 95; Ł. Pohl, Prawo karne. Wykład części ogólnej, Warszawa 2019, s. 224.

${ }^{24}$ Może się zatem zdarzyć przykładowo, iż podżegacz, nakłaniając do popełnienia czynu zabronionego, zamiarem bezpośrednim obejmował będzie jedynie realizację znamion przygotowania zabójstwa, a więc będzie chciał, aby sprawca w celu popełnienia zabójstwa podjął określone wprost $\mathrm{w}$ art. $16 \S 1$ k.k., czy też inne, niewymienione w tym przepisie expressis verbis, czynności mające stworzyć warunki do przedsięwzięcia czynu zmierzającego bezpośrednio do jego dokonania, godząc się, iż może to doprowadzić do dokonania zabójstwa. W takim wypadku możliwa byłaby więc kwalifikacja takiego zachowania z art. $18 \S 2$ k.k. w zw. z art. $16 \S 1$ k.k. w zw. z art. $148 \S 1, \S 2$ lub $\S 3$ k.k. 


\section{PODSTAWA SKAZANIA I WYMIARU KARY ZA PRZYGOTOWANIE ZABÓJSTWA. MOŻLIWE PRZYPADKI ZBIEGU PRZEPISÓW}

Pewne wątpliwości może budzić też kwestia kwalifikacji prawnej przypisanego sprawcy przygotowania zabójstwa, a także charakterystyki podstawy wymiaru kary za takie przestępstwo. Najbardziej sporna w tym kontekście zdaje się rola przepisu przewidującego klauzulę karalności przygotowania przestępstwa, w tym wypadku art. $148 \S 5$ k.k. Wyrażany bywa pogląd, iż przepis taki powinien znajdować się zarówno w podstawie skazania, jak i wymiaru kary. Bezsporne jest natomiast to, iż wykluczone jest $\mathrm{w}$ takim przypadku stosowanie konstrukcji kumulatywnego zbiegu przepisów, obejmującego przepis zawierający klauzulę karalności oraz przepis określający znamiona przestępstwa przygotowanego ${ }^{25}$. Pogląd o podwójnej roli przepisu operującego klauzulą karalności przygotowania należy odrzucić.

Podstawa skazania za przestępstwo przygotowania zabójstwa ma niewątpliwie charakter złożony. Kwalifikacja takiego zachowania, analogicznie jak dzieje się to w wypadku kwalifikacji usiłowania, musi uwzględniać tak zwany modyfikator charakteryzujący czynność, względnie czynności realizujące tę formę stadialną, w tym przypadku art. $16 \S 1$ k.k., oraz jako element zmienny, w zależności od konkretnej treści zamiaru zabójstwa - jeden z przepisów typizujących zabójstwo z art. 148 $\S 1-3$ k.k., wskazanych $\mathrm{w}$ art. 148 § 5 k.k., których realizację sprawca przygotował. Ustaleń sądu zawartych w charakterystyce przypisanego sprawcy czynu wymaga zatem to, do którego z typów zabójstwa sprawca podjął czynności przygotowawcze. Brakuje natomiast podstaw do uwzględnienia w kwalifikacji prawnej przypisanego sprawcy przygotowania zabójstwa art. $148 \S 5$ k.k. Przepis ten nie określa znamion typu czynu zabronionego, a stanowi jedynie „czystą” postać klauzuli karalności przygotowania, wskazując ustawowe granice odpowiedzialności przewidzianej za ten czyn. Podstawa skazania $\mathrm{w}$ takim wypadku powinna mieć więc następujący opis: art. $16 \S 1$ k.k. w zw. z art. $148 \S 1,2$ bądź 3 k.k., z ewentualną możliwością uwzględnienia w kwalifikacji krzyżowania się znamion typów kwalifikowanych zabójstwa, których łączną realizację sprawca zakładał26.

Przygotowanie zabójstwa może pozostawać w zbiegu kumulatywnym z innym przepisem ustawy, gdy czynność przygotowawcza podjęta przez sprawcę na drodze do urzeczywistnienia znamion zabójstwa w formie usiłowania lub dokonania realizuje jednocześnie znamiona innego typu czynu zabronionego. Wejście sprawcy przygotowania zabójstwa w dalsze fazy urzeczywistnienia zamiaru zabójstwa - usiłowanie lub dokonanie — na ogólnych zasadach aktualizuje stosowanie reguł redukcji wielości przestępstw. Pozostają one w zbiegu pozornym.

25 Por. wyrok SN z dnia 2 kwietnia 1984 roku, sygn. II KR 56/84 wraz z glosą Z. Ciopińskiego, G. Kowalczyk, „Problemy Praworządności” 1986, nr 2, s. 70-72; K. Wiak, [w:] Kodeks karny. Komentarz, s. 180.

26 Por. A. Zoll, op. cit., s. 199; A. Liszewska, op. cit., s. 853-854.

Przegląd Prawa i Administracji CXX, 2020, cz. 1 i 2

(C) for this edition by CNS 
Odpowiedzialność za usiłowanie lub dokonanie zabójstwa pochłonie odpowiedzialność za jego przygotowanie. W szczególnym i zapewne w praktyce wymiaru sprawiedliwości wyjątkowym przypadku, w którym sprawca najpierw został prawomocnie skazany za przygotowanie zabójstwa i odbył karę za to przestępstwo, a dopiero później ujawniono fakt usiłowania lub dokonania przez niego zabójstwa, do którego się przygotowywał, powinien on ponieść odpowiedzialność także za usiłowanie lub dokonanie zabójstwa w warunkach realnego zbiegu przestępstw w ramach wymierzonej mu kary łącznej. $Z$ perspektywy idei sprawiedliwości wykluczone byłoby w takim wypadku zastosowanie konstrukcji współukaranego czynu następczego, skoro ten wykazuje znacznie wyższy w stosunku do czynu już ukaranego stopień społecznej szkodliwości, którego wyrazem jest również znacznie surowsza sankcja.

\section{BEZKARNOŚĆ PRZYGOTOWANIA ZABÓJSTWA — ART. 17 K.K.}

Na ogólnych zasadach wynikających z art. $17 \S 1$ k.k. nie podlega karze za przygotowanie zabójstwa ten, kto dobrowolnie od niego odstąpił, w szczególności zniszczył przygotowane środki lub zapobiegł skorzystaniu z nich w przyszłości, a w razie przygotowania jednej z postaci zabójstwa wskazanej w art. $148 \S 5$ k.k. $\mathrm{w}$ postaci wejścia w porozumienie $\mathrm{z}$ inną osobą $\mathrm{w}$ celu jego popełnienia, kto nadto podjął istotne starania zmierzające do zapobieżenia dokonaniu. W tym ostatnim wypadku podstawą bezkarności przygotowania zabójstwa są ,istotne starania” współsprawcy, aby do dokonania zabójstwa nie doszło. Musi on zatem nie tylko dobrowolnie odstąpić od „własnej” części przygotowania, lecz także podjąć działania zmierzające do „neutralizacji” działań przygotowawczych pozostałych uczestników porozumienia co do popełnienia zabójstwa. Przy ustalaniu ,istotności” muszą być zastosowane kryteria obiektywne. Ich doniosłość nie może więc wynikać jedynie z mniemania samego sprawcy. Jeśli natomiast sprawca przygotowania zabójstwa wejdzie w stadium realizacji usiłowania jego popełnienia, a następnie dobrowolnie od dokonania tego przestępstwa odstąpi lub zapobiegnie skutkowi stanowiącemu znamię czynu zabronionego, korzystając z dobrodziejstwa niekaralności usiłowania zabójstwa $\mathrm{z}$ art. $15 \S 1$ k.k., zgodnie z regulacją art. $17 \S 2$ k.k. nie będzie podlegał odpowiedzialności za wcześniejszy etap realizacji znamion przestępstwa objętego zamiarem, a więc za przygotowanie zabójstwa.

Ratio legis tego unormowania wynika z potrzeby zapewnienia bezkarności sprawcy usiłującemu popełnić przestępstwo, który dobrowolnie od jego dokonania odstąpił nie tylko za ostatnie, zrealizowane karalne stadium tego przestępstwa, ale i karalne stadium uprzednie. W przeciwnym razie wynikająca $\mathrm{z}$ art. $15 \S 1$ k.k. klauzula gwarantująca bezkarność sprawcy usiłującego popełnić przestępstwo by- 
łaby w takiej sytuacji w znacznym stopniu iluzoryczna. Regulacja ta wpisuje się w ogólniejszą zasadę, iż przygotowanie ma charakter subsydiarny względem usiłowania. W wypadku więc, gdy usiłowanie sprawcy zabójstwa byłoby bezkarne, nie następuje restytucja karalności za jego przygotowanie.

\section{PODSUMOWANIE}

Wprowadzoną do ustawy karnej mocą art. $148 \S 5$ k.k. zmianę niewątpliwie należy uznać za znaczącą, a nawet fundamentalną. Regulacja ta jest bowiem nie tylko rozwiązaniem precedensowym, lecz także wyrazem zmienionej optyki prawnokarnej ochrony życia człowieka. Przesunięcie tej ochrony na etap przedpola usiłowania zamachu na życie można traktować jako wyraz swoistego dowartościowania tego dobra, którego prawnokarna ochrona w kontekście znamion zabójstwa zaczyna się już wtedy, gdy sprawca podejmuje działania mające dopiero stworzyć warunki do urzeczywistnienia zamachu, a więc zanim rozpocznie bezpośrednie zmierzanie do naruszenia tego dobra.

Rodzi się jednak pytanie, czy jest to zmiana uzasadniona i potrzebna. $Z$ jednej strony niezmiennie aktualne pozostają te argumenty przeciwników penalizacji przygotowania zabójstwa, które nawiązują do trudności procesowych wynikających z dowodzenia realizacji intencjonalnych znamion tej fazy zamachu na życie i ryzyka z tym związanym. Niewątpliwie należy zgodzić się z tezą, iż przypisanie przygotowania zabójstwa jest na tej płaszczyźnie szczególnie utrudnione ze względu na charakter czynności faktycznych mogących realizować znamiona działań przygotowawczych tworzących grunt pod dokonanie tego przestępstwa. $\mathrm{Na}$ tle tego argumentu penalizacja przygotowania zabójstwa w praktyce orzeczniczej w zakresie ochrony życia będzie zapewne prowadzić do znacznie częstszego niż dotąd uruchamiania procesowej zasady in dubio pro reo. Z drugiej wszakże strony zmiana ta będzie przydatna w tych stanach faktycznych, w których nie ma jakichkolwiek wątpliwości, zarówno co do realizacji przedmiotowej, jak i podmiotowej strony przygotowania zabójstwa, zwalniając organy procesowe z konieczności oczekiwania na wejście sprawcy w fazę jego usiłowania, stwarzającego znacznie większe niż czynności przygotowawcze ryzyko dla życia. Ponadto wpisuje się ona w szerszą perspektywę wzmożonej ochrony dóbr podstawowych i uniwersalnych, realizowanej na gruncie prawa karnego na etapie przygotowania przestępstwa i przed omawianą nowelizacją także w zakresie ochrony życia ludzkiego „zintegrowanej” z ochroną innych dóbr prawnych o fundamentalnym znaczeniu, jak też w niekwestionowaną formułę penalizacji narażenia życia na niebezpieczeństwo, bezpośrednie, a także jedynie potencjalne. $Z$ tej perspektywy regulację art. $148 \S 5$ k.k. można uznać za wyraz konsekwencji ustawodawcy i dążenia do spójnego unormowania prawnokarnej ochrony tego dobra. 


\section{CRIMINALISATION OF MURDER PREPARATION IN THE AMENDMENT TO THE PENAL CODE OF 13TH JUNE 2019}

Summary

The article addresses the issue of murder preparation, its essence and legitimacy of penalisation. Such behaviour in the criminal law system under the government's subsequent codifications has remained unpunished. The change in this respect occurred along with the amendment to the Penal Code of 13th June 2019. The adopted modification of the principles of criminal liability on the "foreground of the foreground" of murder raises numerous doubts and controversies. The subject of the study is an attempt to justify the introduced change and answer the question of how the applicable legal status was motivated over the space of almost a century and whether the legislator reasonably departed from the traditional model of impunity for homicide preparation.

Keywords: preparation, murder, criminal record, penalisation, stadium forms, punishment clause, independence clause

\section{BIBLIOGRAFIA}

Bafia J., Mioduski K., Siewierski M., Kodeks karny. Komentarz, Warszawa 1987.

Bojarski T., Polskie prawo karne. Zarys części ogólnej, Warszawa 2006.

Buchała K., Zoll A., Polskie prawo karne, Warszawa 1997.

Ciupiński Z., Kowalczyk G., Glosa do wyroku SN z 2 kwietnia 1984 r., II KR 56/84, „Problemy Praworządności” 1986, nr 2.

Daszkiewicz K., Glosa do wyroku SN z 23 października 1967 r., III KR 113/67, „Orzecznictwo Sądów Polskich i Komisji Arbitrażowych" 1968, nr 7-8.

Daszkiewicz K., Przestępstwa przeciwko życiu i zdrowiu. Rozdział XIX Kodeksu karnego. Komentarz, Warszawa 2000.

Daszkiewicz K., Zbyt wiele niekonsekwencji i chaosu, „Rzeczpospolita” 1998, nr 76.

Kodeks karny. Część ogólna, t. 1, red. M. Królikowski, R. Zawłocki, Warszawa 2011.

Kodeks karny. Część ogólna. Komentarz, t. 1, red. A. Zoll, Warszawa 2007.

Kodeks karny. Komentarz, red. A. Grześkowiak, K. Wiak, Warszawa 2018.

Kunze E., Przygotowanie przestępstwa w ujęciu polskiego prawa karnego, Poznań 1991.

Małecki M., Przygotowanie do przestepstwa. Analiza dogmatycznoprawna, Warszawa 2016.

Marek A., Kodeks karny. Komentarz, Warszawa 2004.

Marek A., Prawo karne, Warszawa 2011.

Pohl Ł., Prawo karne. Wyktad części ogólnej, Warszawa 2019.

Prawo karne materialne, red. M. Bojarski, J. Giezek, Z. Sienkiewicz, Warszawa 2017.

System Prawa Karnego, t. 3, red. R. Dębski, Warszawa 2017.

Świda W., Prawo karne, Warszawa 1989.

Wróbel W., Zoll A., Polskie prawo karne. Część ogólna, Kraków 2010. 